This is an Accepted Manuscript of an article published by Edinburgh University Press in Scottish Affairs. The Version of Record is available online at:

http://www.euppublishing.com/doi/abs/10.3366/scot.2018.0234.

\title{
Campaigning for the Female Vote in the Scottish Independence Referendum: Comparing Women For Independence and Women Together
}

\section{Craig McAngus ${ }^{1}$ and Kirstein Rummery}

\begin{abstract}
$\underline{\text { Abstract }}$
The 2014 Scottish independence referendum campaign saw a surge of campaigning activity from groups on both sides of the debate. The mainstream elements of the campaign were criticised for not bringing enough attention to women's issues, and so Women For Independence (WFI) and Women Together (WT) were created in order to try and alleviate these concerns. This paper aims to compare the two organisations to ascertain whether or not they can be classified as part of wider social movements. Utilising data from the Scottish Political Archive at the University of Stirling, as well as face-to-face interviews and email conversations with activists from both groups, this paper explores the organisational structures and framing strategies of the two groups, as well as the opportunities and constraints they faced when it came to achieving their goals. Whilst WFI can be classified as a Social Movement Organisation operating within both the pro-independence and women's movements, WT cannot be classified in this way and simply existed as a useful campaigning label during the independence referendum. WFI still continues to exist as a healthy, autonomous entitythat, should a second independence referendum be called, will be in a strong position to campaign for the female vote and overturn the persistent gender gap that exists in support for Scottish independence.
\end{abstract}

Keywords: Social movements, political campaigns, feminism, referendums, Scottish independence

Craig McAngus is Lecturer in Politics, Department of Politics and International Relations, University of Aberdeen

\footnotetext{
${ }^{1}$ Corresponding author
} 
Kirstein Rummery is Professor of Social Policy, Faculty of Social Science, University of Stirling 


\section{Introduction}

The Scottish independence referendum saw an unprecedented surge in activity froma wide range of campaigning groups and organisations. This surge was coupled with heightened political interest amongst the public, with $84.6 \%$ of the electorate turning out to vote in the ballot. Because the referendum question was asking, essentially, whether or not Scotland should be an independent state, a vast range of political issues were debated and discussed. In quite a few cases, organisations and groups formed to focus and campaign on specific issues and policy areas. One such issue was that of women and gender equality, with the creation of two organisations during the campaign: 'Women For Independence' and 'Women Together'. These two organisations focussed their efforts on securing the female vote for both Scottish independence and continued membership of the UK respectively.

The aforementioned organisations explicitly aimed to persuade women to vote either Yes or No, but this does not mean that occurred from a feminist perspective. An organisation created to win women's votes is different from a women's organisation seeking to use the vote to address structural inequalities in political institutions, the economy and wider society. This would change the nature of an organisation from being a simple campaign organisation to being part of a wider movement. This paper seeks to address the question of whether or not Women For Independence and Women Together can indeed be situated in the wider women's movement. The paper aims to do this through the use of literature on social movements in order to assess the opportunity and constraints, organisational profiles and framing processes of both organisations.

The paper is split into three main sections. The first offers a brief background to the referendum campaign the role that women's organisations and feminism had during this period. The second part offers an analytical framework for analysis based on literature on social movements, as well as a brief overview of methodology and data. The third section looks at, based on the social movement literature, the activities of both organisations in terms of their political opportunities and constraints, their organisational profiles, and how they framed the Scottish independence. The 
conclusion offers a summary of the empirical discussion and assesses whether or not the two organisations ought to be classified as part of wider social movements.

\section{The Scottish independence referendum - an opportunity for women's engagement?}

The latter stages of the independence referendum campaign saw a multitude of different organisations campaigning for both a Yes and a No vote. Despite this, the campaign was largely dominated by two main organisations, Yes Scotland and Better Together, who campaigned for a Yes and a No vote respectively.

From the point of view of advocates of Scottish independence, the prospect of independent statehood provided opportunities for potentially radical change to the economy, political system and welfare state. Groups such as Radical Independence, the Common Weal and parties such as the Scottish Greens advocated a vision of independence that was markedly different from that offered by the SNP-run Scottish Government. With regards to women, 'Women For Independence' (WFI) were the main pro-independence organisation active during the referendum campaign. On the pro-UK side, equivalent activity was far less visible and pronounced, although an organisation called 'Women Together' (WT) was created in order provide some sort of counteracting effect to the activities of WFI and give a voice to women who would be voting No.

It has been argued that a 'British women's movement' does not exist. One supporting element of this proposition is that a large collection of single-issue organisations pressing for feminist aims exists without actually constituting a movement (Mackay, 2008: 21). Another reason is the governance of the UK itself: often wrongly referred to as a unitary state, the UK exists as a 'state of unions' (Mitchell, 2009) which in turn encourages venue shopping (Keating et al, 2009) due to governance operating on multiple levels. Ever since the Anglo-Scottish union in 1707, Scotland has always had a substantial degree of autonomy, broadly defined (Mitchell, 2014a), and so women's organisations have always engaged with Scottish institutions when it came to policy, even more so from the 1980 s onwards in the context of debates around devolution (Mackay, 2008: 25).

The independence referendum presented a unique opportunity for feminist arguments for and against Scottish independence to be posited and debated. Kenny 
(2014), however, argues that such developments were, on the whole, not forthcoming in the sense that a feminist perspectivewas largely missing from the debate and the Scottish Government's white paper on independence failed to present a coherent set of policy and constitutional proposals solutions for tackling gender inequality. Relatedly, McAngus and Rummery (2017) argue that the proposals in the white paper to extend childcare, although welcomed, were not framed as a method for promoting gender equality. Unlike in Sweden for example where childcare policy was traditionally framed explicitly as a gender equality issue (Hiilamo and Kangas, 2009), the Scottish Government's proposals for extending childcare were framed as a method of boosting female employment and encouraging economic growth (McAngus and Rummery, 2017).

It would however be a mistaketo say that women were not involved in the campaign itself. Nicola Sturgeon, then Deputy First Minister, was extremely active during the campaign, as were former leader of Scottish Labour Johann Lamont and Scottish Conservative leader Ruth Davidson. Outside party politics, both WFI and WT were active during the referendum campaign, both in the media and in local communities. However, as this paper will discuss, WFI and WT were very different in terms of their objectives and aims, organisational structure, and the way in which women's issues were framed. Using literature on social movements, an analytical framework will be offered through which various features of both WFI and WT can be analysed in order to ascertain whether or not they can be classified as part of a social movement or not.

\section{Recognising (or not) a movement - An analytical framework}

The independence referendum resulted in the formation, as mentioned above, of Yes Scotland and Better Together. Despite a range of fundamental differences between these two organisations, they were both cross-party organisations that set out to garner public support for Scotland becoming either independent or remaining within the UK. However, it would be a mistake to say that these were the only two organisations involved in the referendum campaign. Indeed, a plethora of organisations and groups sprung up that campaigned, often quite independently, for either a Yes or a No vote. 
This paper seeks to address and analyse WFI and WT's organisational identities and how this affected how they framed and argued their message regarding the referendum in order to identify whether they can be situated within a wider movement. Social movements are collective, organized efforts at social changeexisting over a 'period of time' by engaging in a 'conflictual issue' with a 'powerful opponent', populated by members who share a 'collective identity', and who pursue change by employing protest (Edwards, 2014: 4-5). Social movements experience both successes and failures during their lifetime, and the fact that Scotland voted No should not have prevented WFI for continuing its activities, albeit in a different context. The same applies to WT. If we are to classify WFI and WT as part of wider social movements, then we would expect to see them continue to 'mobilize their constituency for collective action' with a 'political goal' in mind. Women's movements ebb and flow, taking on different forms both inside and outside of state institutions (Sawer and Jamieson, 2014), often moving into a state of abeyance but maintaining challenging discourses (Sawer and Grey, 2008). So, although the referendum may have represented an important objective, it would not be fundamental for the survival and continued activity of either WFI or WT.

In order to compare the two organisations and potentially place them in the wider context of a social movement, McAdam et al's (1996: 2) theoretical framework for the comparative analysis of social movements and their component units will be adopted in order to direct the empirical discussion. The framework looks at the following factors:
1. Political opportunities
2. Mobilizing structures
3. Framing processes

The first, political opportunities, considers the opportunities afforded to social movements and the subsequent constraints in terms of achieving goals and objectives. Indeed, 'most political movements and revolutions are set in motion by social changes that render the established order more vulnerable or receptive to challenge' (McAdam et al, 1996: 8). The independence referendum offered an opportunity in that it was a high-profile policy area that drew attention to a broad range of issues, including gendered ones, but also existed as a threat to the 'political authorities', namely the UK Government and those who supported continuing 
membership of the UK, because of the 'national interest' profile of the referendum and the preceding campaign (Kriesi et al, 1995: 97). However, opportunity (and constraint) structures are more complex than those rooted in formal political opportunities (McCammon, 2001). Public opinion thus represented a significant opportunity or constraint (Schuck and de Vreese, 2009), depending which side of the debate one happened to be on.

The second refers to the forms of organizational structures available and utilised. Social movements are not monolithic entities, and there is a rich diversity of collective settings in which they develop and the organisation forms they take on (McAdam et al, 1996: 4). For example, within larger entities that could be described as social movements, social movement organisations (SMOs) act autonomously on more specific objectives within the overarching objectives of the overall social movement. Although a range of formal organisations can be found within the context of a social movement, Kriesi (1996: 152) states that:

SMOs are distinguishable from the other types of formal organisations (supportive organisations, movement associations, parties and interest groups) by two criteria: (1) they mobilize their constituency for collective action, and (2) they do so with a political goal, that is, to obtain some collective goal (avoid some collective ill) from authorities.

SMO's are thus autonomous entities within wider movements and advocate collective aims, such as feminist ones. If WFI and WT are to be considered as SMO's that contribute to the aims of a wider movement of women's liberation and gender equality, then the empirical evidence would be expected to show organisational independence, autonomy of message, and the pursuit of a niche that perhaps the wider movement overlooks or does not pay enough attention to.

The third refers to the collective process of interpretation, attribution and social construction that mediate between opportunity and action. In other words, the meanings and definitions that are shared are important, and a sense of grievance is required (McAdam et al, 1996: 5). All three of the aforementioned factors are intricately intertwined, and so talking of them in isolation from one another is only for the benefit of organising empirical analysis. For example, as McCarthy (1996: 149) argues, organisational structures are themselves part of the framing contest that ensues between opposing forces. For members of social movements, they will 
frame the structure of their organisation as one that is appropriate and legitimate when it comes to backing a particular cause, while opponents will attempt to delegitimise those same structures.

\section{Methods and Data}

The paper adopts a qualitative approach to data analysis, with some graphs being used to portray some descriptive data using the Scottish Social Attitudes survey. The main bulk of the data comes from three sources. The first is from six interviews from three WFI and three WT activists. These interviews were conducted between April and June 2014. The interviews are anonymous and the interviewees are referred to as 'activists' along with the date when the interview was conducted. The second source of data comes from email correspondence with two individuals, one from WFI and one from WT, who were involved in key administrative and organisational roles. These correspondences are referred to as 'organisers' and were conducted in February 2015 on more than one occasion. The third data source comes from the Scottish Political Archive (SPA) at the University of Stirling. The SPA houses a major collection of material from the independence referendum, and all materials are referenced by their catalogue number (e.g. SPA/2558). ' Campaign materials such as flyers, leaflets, newspapers and briefing notes were used to triangulate other sources of data.

There were difficulties in collecting data on WT. The Better Together website hosted the WT section, and that has been taken offline since shortly after the referendum. Snapshots of the archived website are available at the National Library of Scotland but yielded little relevant data. Also, the SPA struggled to get hold of much material from WT, which was in stark contrast to WFI. However, enough data does exist and is publicly available for triangulation purposes, but not the same extent as in the case of WFI. The arguments laid out below regarding the organisational independence (or lack) of WT from Better Together shed light on why this is the case.

\section{Winning (or defending) the vote - opportunities and constraints}

As alluded to previously, the referendum opened up a discursive space whereby the possibilities afforded by independent Scottish statehood could be discussed, as well as the advantages Scotland enjoyed and could expect to enjoy by remaining as part of the UK. Although the official referendum campaign lasted a matter of weeks, the 
campaign effectively began soon after the SNP won a parliamentary majority at 2011 Scottish election. Barely a day went by without an independence related issue making the headlines.

In early 2012, the founding members of what would become WFI held a meeting in order to discuss the possibility of forming a group that would bring a gendered focus to the campaign for Scottish independence. WFI therefore began its life in early 2012, around April or May according to different accounts, but was officially launched in September 2012. According to their website, WFI promotes the causes of Scottish independence and other constitutional changes likely to contribute to greater democracy and home-rule for Scotland, gender equality and social justice' through 'working to increase women's political engagement, nationally and in communities' (Women for Independence, 2014). One key aim was to counter the disproportionately 'masculine' nature of Scottish politics: political debates are often dominated by men, and even the online debates on Twitter during the referendum were clearly lacking a deliberative edge in terms of equality of gender participation (Quinlan et al, 2015).The founding members came from a range of different professional and political backgrounds but shared a commitment to engaging with women directly and bringing a gendered focus to the pro-independence campaign. The salience of the referendum also provided an opportunity to engage with women in an in-depth manner that had previously not been possible, at least since before devolution in 1999.

\section{< FIGURE 1 ABOUT HERE $\gg>$}

The opportunity to form a pro-UK, feminist organisation was also opened up by the referendum. However, WT was not launched until International Women's Day 2013, a full 6 months after WFI was officially launched. It would be wrong to suggest that individuals who had previously and publicly stated that they were feminists were not involved in the pro-UK campaign, but their activity was largely taken up within political parties and trade unions, amongst others, and not primarily within the context of a pro-UK, explicitly feminist organisation like WFI. One explanation for 
this is the state of public opinion in the earlier part of the campaign: opinion polling consistently showed that women were more sceptical of independence than men (figure 1) and indeed remained that way with regards to the actual result of the referendum (figure 2).

\section{$\ll$ FIGURE 2 ABOUT HERE $\gg$}

The state of public opinion meant that, for WFI, there was a significant constraint in place which facilitated an 'uphill battle' type of campaign (Leduc, 2002: 728). Women were indeed more 'unsure' than men regarding the consequences of independence (figure 3) and historically shown lower levels of support for independence than men (figure 4). The creation of WT can thus be understood as a defensive move from the pro-UK campaign aimed at consolidating support for the UK amongst women. Indeed, one WT activist stated that her media appearances on TV and Radio were 'a kind of contrast' to provide some 'counterbalancing arguments' at the request of Better Together (Interview with WT activist, 9th June 2014).

\section{$<$ FIGURE 3 ABOUT HERE $>$}

Parallels can be drawn here with the 1982 referendum on legalising abortion in Ireland. In that case, public opinion was firmly behind the idea of maintaining the illegality of abortion, yet a powerful pro-life lobby formed in 1980 in anticipation of a pro-choice lobby that they perceived would gain traction as a result of inspiration from the UK and the USA (O'Leary and Hesketh, 1988). Groups will thus form in a referendum context from a position of strength in order to counteract a perceived threat from the opposing side. 
Despite WFI campaigning for a Yes vote and naturally being disappointed by the result of the referendum, the group is still very active in terms of promoting women's issues, campaigning for gender equality, and focussing attention on the gendered implications of constitutional reform. WT ceased activity the day after the independence referendum and were wound down along with Better Together. Their Twitter account shows no activity from that period and so, as an organisation, it is not involved in any form of post-referendum activity whatsoever. That is not to say that women who were involved in WT are not actively engaged in politics, but this engagement is not carried out in a WT capacity. This is in stark contrast to WFI. As Sawer and Grey (2008: 3) highlight, women's movements are often associated with 'dissent events', in this case the independence referendum, but this overlooks the fact that they mobilize collective identity and sustain challenging discourses. WFI have continued to be a very active organisation which campaigns on a number of issues that are not necessarily linked to independence.

\section{Organisational profiles - dependence or independence?}

As outlined above, WFI began life officially in September 2012. By that time, Yes Scotland had been founded and begun its campaign activities. However, from a proindependence point of view, a number of feminists felt that the campaign was not doing enough to take a gendered perspective and engage directly with women's issues. The solution, according to them, was to set up an autonomous and separate organisation that would rectify this problem. According to one WFI activist: 
...we wanted to be involved on our terms autonomously, both in terms of promoting women's voices in the independence referendum, but ensuring that women's interests and needs were at the centre of any discussion in terms of the referendum. And so, realised very early and it still persists, hopefully narrowing - that were was a gender gap in terms of support for independence and we didn't really have confidence that the mainstream movement, either party politics or the Yes Scotland campaign, would understand that enough and do enough. So, it had strategic aims but also it was about method and quite a number of women came together who were disenchanted with their previous experience of activism and wanted a safe, autonomous space for women to pursue a Yes vote and in the interests of women.

(Interview with WFI activist, 10th April 2014).

From its inception, WFI was completely autonomous from Yes Scotland. Indeed, at Yes Scotland's launch event, the only woman involved was Elaine C. Smith who, in her statement to the press, did not mention gender equality or related issues at all (SPA/815/5). WFI was therefore created to counteract this and exist as 'a women's movement - by women, for women, - supporting independence' (SPA/863/2). The organisation ran its own engagement events, ran its own website and mailing list, and produced its own campaign material and literature. This is not to say that members of WFI were not engaged with other pro-independence organisations and political parties however, as many of the founding members had a history in party politics including Scottish Labour, Greens, SNP and the Scottish Socialists. But in terms of its relationship with Yes Scotland, WFI was very much an independent organisation, and the majority of campaigning time by its leading figures was spent in the context of WFI (Interview with WFI activist, 24th April 2014).

WFI only started a centralised membership scheme in February 2015, and at that point had about 300 members. Until that point they were a loose network of local groups, and the only idea of membership numbers came in form of who had signed up for mailing lists and names that had been 'gathered' from lists of who had attended public meetings and events (Email correspondence with WFI Organiser, 10th February 2015). Since the referendum, WFI has been evolving in organisational terms. A constitution was ratified at the organisation's AGM in March 2015, coupled with an election for members to choose a National Committee which is now operational. As one WFI organiser stated, these developments meant that WFI was now 'basically up and running as a fairly large organisation' (Email 
correspondence with WFI organiser, 10th February 2015). The organisation is becoming more professionally structured, with data, networking and communications capacity being built into a single website. All affiliated groups are to be given their own sub-pages for campaigning purposes. Local groups will be left to largely organise their own campaigns and issue-based meetings, whilst at the national level WFI will focus on more training-based events for members and local groups to maximise their effectiveness (Email correspondence with WFI organiser, 10th February 2015). Rather than seeing a No vote lead to the withering away of WFI, the organisation is becoming more professional in its operation and adapting well to the landscape of Scottish politics that has emerged since September 2014. In organisational terms, WFI can very much be described as an SMO.

A WT activist implied that WT was a grassroots organisation that had local groups across Scotland. For example, WT would hold 'meetings up and down the country' and operate 'in local areas' in 'a more informal environment' (Interview with WT activist, 28th May 2014). Another interviewee discussed the public meetings that WT held in more detail:

...we run some events whereby we invite women to bring along a friend who is undecided to a more kind of informal thing. There's the usual welcome and introduction, a bit of a spiel from maybe someone like Jackie Baillie or Margaret Curran or Johann Lamont's done it as well, and then it's just a kind of open, you know, cheese and wine set up type thing and people just go around and they chat amongst themselves, and so it's obviously planned so that there's a number of key activists from within the Women Together campaign to talk to other women...

(Interview with WT activist, 19th May 2014)

Women were invited to 'bring a friend' who was undecided on how they would eventually vote in the referendum. These events were not public however, and only women who were signed up to WT were invited along although they were asked to 'bring a friend' along to those meetings (Email correspondence with WT organiser, 26th February 2015)." Of the three interviewees that were put forward by Better Together as being part of WT, none of them stated that the bulk of their campaigning energy were used in WT, but rather in Better Together itself or within one of the proUK political parties, usually Scottish Labour. The fact that the events held by WT were invite only, exclusive and largely absent 'on the ground', coupled with the 
organisational dependence on Better Together, points to WT being less of an organisation in its own right and more of a label deployed by Better Together in order

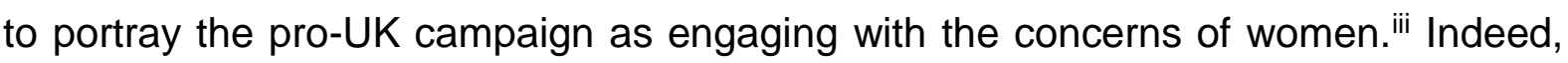
the method of engagement with women was far more akin to the approach used by Better Together generally which was based on a professionalised party political approach and dominating the traditional media agenda (Mitchell, 2014b).

WT was formed after WFI in order to provide some counterbalance, but it was also founded to provide a voice and a platform for women who were intending to vote No in the referendum (Email correspondence with WT organiser, 26th February 2015). However, WT did not exist as an independent organisation and was part of the Better Together organisation and campaign (Email correspondence with WT organiser, 26th February 2015). Furthermore, within Better Together, WT was spearheaded by a small, core campaign team with Blair McDougall, Better Together's Campaign Director, 'very involved with all aspects of stakeholder engagement' (Email correspondence with WT organiser, 27th February 2015). In the description section of WT's official Twitter account, the address of the 'organisation' is simply Better Together's address in Glasgow, and McDougall is stated as WT's promoter (Women Together, 2014a). The fact that McDougall carried out such an important role in WT's operations is further proof that the organisation was more of a campaign label rather than an independent organisation like WFI.

\section{Framing the referendum - a feminist perspective?}

The independence referendum campaign offered feminist actors the opportunity to campaign on the grounds that different constitutional options would be more conducive to making Scotland a more gender equal society. However, as Kenny (2014) has outlined, the constitutional question facing Scotland did not have the same consideration of gender issues as the campaign for devolution did in the $1980 \mathrm{~s}$ and 1990s. Bell and Mackay (2013) make a similar point, and argue that the legalistic process of putting an agreed programme for the holding of the referendum in place has led to the narrowing of a deeply complex and important question into a binary choice. Nevertheless, WFI and WT used the referendum campaign as an opportunity to frame the question of how Scotland, both within and outside of the UK, could be transformed and become a country for women to live and work in. 
WFI framed the independence referendum as an opportunity to construct a new, more gender equal Scotland, but also attempted to portray the UK as a hindrance to the achievement of such aims. In terms of constructing a 'new' Scotland, a Yes vote in the referendum was an opportunity to start afresh and fundamentally shape and alter the existing power structures so that they were more conducive in the promotion of a more gender equal society (SPA/2523). One such avenue for the achievement of such ends was the adoption of a written constitution which hadthe potential to enshrine clauses aimed at promoting gender equality in supreme law. In the words of one interviewee;

...gender inequality is fundamentally about power and equality of power, and so I think if the constitution deals with power and where it sits then so it would be about things like representation, but it could say things like 'women WILL be treated equally to men', it could reverse the burden in terms of employment law, for example, individual women have to pursue sex discrimination claims or individual pay claims with all the resources that that entails for an individual to be able to identify a comparator or identify that that man is getting paid more than them, etc.

(Interview with WFI activist, 10th April 2014)

Constitutions can, of course, be 'gendered' in that they can be designed in that they can ensure that women are included as full members of the 'constitutional community' (Irving, 2008: 109). A written constitution could, as Irving (2008: 24) points out, 'mirror values and incorporate aspirations' that reflect the type of Scotland that they would like to see and that women ought to live in. Explicit commitments to gender equality and mechanisms to ensure equal representation in public life are two examples of the types of clauses activists in WFI would want to see in an Scottish constitution (Interview with WFI activist, 10th April 2014; Interview with WFI activist, 24th April 2014). Importantly, the possibility of achieving these developments is presumed to be nearly impossible within the context of the UK and WFI attempted to frame the idea of a constitution as such.

WFI also discussed the possibility of independence as a mechanism policy structures and approaches. Independence would have seen full control of welfare and taxation policy, and this transfer of power presented an opportunity to shape policies that were more sensitive to gender issues. Natalie McGarry, one of WFI's most prominent activists, stated in a speech at Glasgow University in February 2013 
in reference to more gender equal states that 'the high standards of these countries though by no means perfect - weren't achieved by waiting for the male, pale and stale in boardrooms and committee meetings to get round to acting' (SPA/0688). In other words, the existing male-dominated power structures in economic and political life would need to be radically transformed by feminist action to bring about 'a transition to a framework of gender equality that we can only dream of under the Westminster monolith' (SPA/0688).

Independence is also an opportunity to change the dominant economic structures in Scotland. Economic inequality is an issue that WFI framed as not only important, but that the traditional and mainstream approach to economics was very 'male dominated' with regards to 'what amounts to desirable economic activity and industry' (Interview with WFI activist, 25th April 2014). Furthermore, the referendum had been framed in a very 'male' manner on the whole, and WFl's intent was to shift the focus towards policies like extending child care and to think about such policies as infrastructure investments (Interview with WFI activist, 24th April 2014). WFI activist briefing notes state that the 'burden of responsibility for childcare falls heavily on women's shoulders' and 'the lack of access to and relative affordability of decent childcare' negatively 'affects women's career prospects and economic prosperity' (SPA/1063). Independence opens up opportunities to create a 'more balanced and fair labour market in terms of gender' and 'address wider societal issues around attitudes to women' in a Scotland that is 'still a substantially and historically patriarchal society' (SPA/1063). This represents a clear feminist approach to the framing of independence and an explicit attempt to consider the opportunities on offer in the referendum in a way that bypassed traditional, 'male' paradigms.

Alongside the opportunities offered by independence, the failings of the UK were also articulated and framed in terms of undermining the cause of gender equality. All of the opportunities mentioned above weremore difficult to achieve within the UK because of the slim chances of implementing a written constitution, reversing welfare reform and putting a more progressive system in place, and advocating an alternative economic approach to austerity (Interview, with WFI activist, 10th April 2014). The UK, often also perpetuates a traditional, 'male' approach to policy and sovereignty, with the UK's fleet nuclear submarines commonly cited as an example of misplaced priorities (Interview with WFI activist, 25th April 2014). In a leaflet 
distributed around WFI's official launch in September 2012, the UK's foreign and defence policy is dismissed as 'money wasted in 'bossing the world' in illegal wars' and independence is cited as a route through which Scotland can get rid of '200 nuclear bombs on the Clyde that could kill millions of people indiscriminately' (SPA/838/2). Framing the risk of remaining in the UK was thus an important aspect of WFl's message alongside shining a positive light on Scottish independence.

WFI therefore articulated its own independent message and framed Scottish independence as a way in which gender equality could become a more likely prospect. The group's full name has always been 'Women for Independence Independence for Women' (SPA/838/2) and signalled WFl's intention to be an organisation that not only campaigned for independence, but that aimed 'to ensure women are involved in the independence debate' (SPA/1022/2) and promote women's political engagement more generally.

Documentary evidence shows that WFI developed a more pronounced and explicit feminist message as time went on. Early campaign literature from 2012 and 2013 argued for independence on similar terms to Yes Scotland (Scotland will be wealthier and have a fairer welfare system, for example) and fails to make any mentions of gender equality, either explicitly or implicitly (SPA/838/2; SPA/925; SPA/1022/2). However, WFl's framing of the question of independence does develop a more feminist message from early-2014 by explicitly referring to the impact of welfare reforms specifically on women (SPA/1063), the enshrinement of women's rights in a constitution (SPA/2523) and the relationship between childcare and gender equality (SPA/2320). Therefore, by 2014, WFI was clearly framing independence in feminist terms and attempting to persuade women that that not only their interests were best served by voting Yes, but that Scottish independence was the best method for undermining and changing patriarchal power structures in political institutions, the economy and in wider society.

Although WT had a different objective from WFI, there was a similar but opposite framing process in the sense that the notion of independence was attacked on the basis that it was a huge risk, whilst the UK was defended on the basis that it bestowed women with a more stable platform upon which to seek gender parity with men. Beginning with independence as a risk, one Better Together campaign 
newspaper featured a small section in the name of a WT activist, and stated that 'leaving the UK would be a big irreversible risk... [if] we go it alone there would be no going back' (SPA/2558). The same newspaper also accused Alex Salmond, former First Minister and leader of the SNP, of peddling 'false promises' and a 'dodgy deal' that women will be able to see right through (SPA/2558). Historical support for independence has indeed been lower amongst women compared to men (figure 4 above) and so highlighting the potential risks of independence were clearly intended to make sure that this was maintained.

The risks that independence represents are couched very much in the notion of irreversibility and economic uncertainty. Better Together consistently argued that Scotland was economically more prosperous within the UK, and this economic prosperity allowed Scotland's spending per head of population to be higher than in the rest of the UK. For women, the fact they 'rely disproportionately' on the health service and social care, amongst other public and social services, means that staying within the UK provides 'more resources at our fingertips' for ensuring a stable and adequately funded public sector moving forward (Interview with WFI activist, 19th May 2014). Another WT interviewee elaborated further;

Well I think if you look at the way women are affected economically, they're still the most affected by the cuts, for example, women disproportionately affected by cuts to the welfare state, women are more likely to be at home... and I think as part of the UK, when we're part of a bigger economy, you know, mortgages are safeguarded, we get better protection from kind of financial impacts.. that's why we're better off in the UK because it's women that are always disproportionately affected by economic hardship and I think that Scotland would be economically worse off independent as opposed to not.

(Interview with WT activist, 28th May 2014)

Alongside the risks of independence, the UK was presented as an entity that, because of its size and its capacity to foster solidarity across its constituent nations, was a better prospect for women's rights. Interviewees from WT did not suggest that the UK provided anything like a fair deal for women in terms of equality, but there was scepticism that independence could deliver better opportunities and a belief that building on the existing state framework was the best solution going forward. In the words of one interviewee; 
as a feminist... my conclusion is I would rather stay within the four nations, build on the advantages that we enjoy for being part of that and work on the areas that unarguably are just rank and need to be addressed, but do it from a position of strength, don't weaken yourself before you get out the starting block, and carry on working and fighting for the kind of values that I believe in as a feminist.

(Interview with WT activist, 7th July 2014)

Furthermore, by being part of the UK, Scottish women are able to tap into the wider achievements of women across the UK and enjoy the sense of solidarity that is created by being part of a larger entity (Interview with WT activist, 19th May 2014). This message was also articulated during the campaign by Harriet Harman, former Deputy Leader of the Labour Party, who framed the struggle for women's rights and gender equality as more effective when it was fought on a pan-UK basis, and appealed to 'sisters' by stating that they are 'better together' in the UK (Harman, 2014). This appeal is similar in nature to the often used Better Together slogan of 'best of both worlds' where Scots 'can have a strong Scottish Parliament, with the guarantee of more powers for Scotland, back up by the strengths, security and stability of being part of something bigger' (SPA/2558). Crucially, however, these messages were not put across by WT but rather feminist women operating in different capacities. Women were arguably more receptive to such messages give that their support for devolution as has been consistently higher than men's since 1999 (see figure 5).

\section{$<$ FIGURE 5 ABOUT HERE $>>$}

Women who would describe themselves as feminists were involved in WT, but there is little evidence of WT articulating a pro-feminist argument for continued membership of the UK. As outlined above, the arguments put in favour of the UK regard the collective endeavours that had been achieved by women within the UK up to the referendum campaign. Indeed, for WT, the prospect of Scottish independence is one that would likely take women backwards from the gains that they have already made. This is in stark contrast to arguing that the UK is a vehicle in which feminism can be best advanced, and the structure of the British state, its economy and its 
welfare system are the springboard for achieving gender equality. In other words, rather than promoting the UK as a route to greater gender equality, the dangers of Scottish independence were given more weight.

Furthermore, despite activists from WT using feminist language in their interviews, the evidence of WT together using such language publicly is sparse at best. For example, their Twitter account (Women Together, 2014a) is laden with retweets of Better Together tweets which do not offer any feminist criticism of independence or appraisal of the UK. Many of the retweets are of women who supported a No vote, but they are generally making 'general' arguments for voting No that would normally be used by Better Together. Even the tweets from WT itself are general campaign rhetoric, normally borrowed from Better Together, such as 'we have $£ 1200$ more per person to spend on public services than if we went it alone' (Women Together, 2014b) and 'as part of the UK, Scotland keeps the pound - and the Bank of England standing behind us' (Women Together, 2014c).

In August 2014, WT launched a book entitled 'Women Saying No: Making a Positive Case Against Independence' (Fyfe, 2014; The Scotsman, 28th August 2014). The book is edited by former Labour MP Maria Fyfe and features on a range of topics including national identity, internationalism, welfare and pensioners. The chapter by Maria Fyfe herself is entitled 'Why a No Vote is Best for Women', yet there is no feminist analysis of the risks of Scottish independence and the benefits of current UK membership. The chapter duly lists a number of achievements in the UK that have been beneficial to women, such as the 1967 Abortion Law reform, the introduction of Child Benefit, and the Equal Pay and Sex Discrimination Acts, but criticises the prospect of independence largely on the basis that is a project that belongs to the SNP. For example, the 'Scotland's Future' document is referred to as 'their own White Paper' (Fyfe, 2014: 36). The other chapters are almost entirely bereft of feminist analysis of the issues that were prominent during the campaign.

Prominent women involved in Scottish Labour, namely Jackie Baillie, Margaret Curran, Johann Lamont and Kezia Dugdale, were associated with WT and featured on panels at WT events. However, this was not their main focus, and many of the speeches that they made that promoted gender equality and highlight their feminist credentials were made in the context of their political party and not in WT. A much 
criticised Better Together TV broadcast, entitled 'The woman who made up her mind' (Better Together, 2014), featured a woman who was unsure about the decision she faced in the referendum and essentially made up her mind to vote No because 'independence seems like one big gamble' and that she would 'not be gambling with her childrens' future'. Fiercely criticised for being 'sexist and patronising' (The Guardian, 27th August 2014), the advert showed that the pro-UK message was largely under the control of Better Together and, as such, left virtually no room for a feminist perspective on an independent Scotland or the UK. Unlike WFI who had a committed core of activists running an organisation that was completely independent of Yes Scotland and who made WFI their key focus, WT was essentially a label that Better Together adopted in order to defend and promote the female No vote. The lack of a feminist perspective in terms of how the referendum was framed was a direct result of WT's lack of organisational independence.

\section{Conclusion}

The campaigns on both sides of the independence debate contended with a multitude of issues, policies and arguments around whether or not Scotland should have voted Yes or No. Women's issues were one part of this complex reality. It became clear some time before the referendum that whatever side was able to convince a majority of women to vote for their vision of Scotland's future would likely win the referendum. Both sides of the debate attempted to engage with female voters, but they way that they did so was very different.

By the final stages of the campaign, WFI had shown itself to be an explicitly feminist organisation. It used arguments about patriarchal power structures and unfair policies and representative institutions to outline a feminist case for Scottish independence. Their independence from Yes Scotland and their continuing role in Scottish politics as a campaigning organisation signifies their status asan SMO, straddling the overlap between a broader woman's movement in Scotland and the independence movement. Despite being on the losing side of the referendum, WFI has continued to play an active, campaigning role in Scottish politics. WFI continues to advocate independent statehood for Scotland, but their campaign activities have broadened out significantly and thus can be considered as part of the wider women's movement in Scotland. 
WT ceased to exist after the referendum. The last tweet made from their Twitter account was made at 8pm on the 18th of September, retweeting Better Together's plea to vote No for 'fast, better, safer change'. The fact that WT was never separate and autonomous from Better Together hampered its ability to foster a message that was publicly feminist. Despite feminists being involved in engagement and publicity events, most of their activity was undertaken within different organisations in the wider pro-UK campaign. The evidence points strongly towards WT simply being a label to highlight why women would be voting No as opposed to advocating a feminist justification for Scotland's continued membership of the UK. This is not to say that such arguments were not made during the referendum campaign, but there is little evidence of them being made through WT. This distinction was nurtured in part by the organic and 'bottom-up' nature of the pro-independence movement, whilst the more elite-driven, 'top-down' approach taken by Better Together left less room for autonomous activity by affiliated groups.

The continued existence of WFI is testament to their resilience and relevance as an organisation, but also the continuing existence and activity of the pro-independence movement in Scotland. It also highlights that there is some overlap between this movement and the women's movement, with $\mathrm{WFI}$, as an SMO, operating as a bridge between the two and campaigning in a way that promotes the aims both movements. Given that the UK is currently negotiating its exit from the European Union (EU) and Scotland voted decisively to remain within the EU then there is every chance that a second independence referendum will be held at some stage in the next decade. WFI will have learned from the first referendum and will be campaigning from a much higher base of support for independence amongst women compared to when it started out. This is the case for the pro-independence movement as a whole, and WFI will set out in any new campaign with a stronger organisational profile, an engaged and energised membership, and the experience that comes from the first referendum with regards to strategy and message. 


\section{Bibliography}

Bell, C. and Mackay, F (2013) 'Women and constitutional debates: engendering visions of a new Scotland' in Hassan, G. and Mitchell, J. (eds) After Independence (Edinburgh: Luath Press Limited) pp. 259-271

Better Together (2014) The woman who made up her mind, 26th August 2014 [accessed 24 March 2015] https://www.youtube.com/watch?v=OLAewTVmkAU

Edwards, G. (2014) Social Movements and Protest (Cambridge: Cambridge University Press)

Fyfe, M. (ed) (2014) Women Saying No: Making a Positive Case Against Independence (Edinburgh: Luath Press Limited)

Guardian, The(2014) \#PatronisingBTlady: How Better Together's latest ad went wrong, 27th August [accessed 24th March 2015]

http://www.theguardian.com/technology/2014/aug/27/patronisingbtlady-how-better-

togethers-latest-ad-went-wrong

Harman, H (2014) An appeal to women in Scotland. "Sisters - we are better together!" LabourList, 9th September [accessed 24th March 2015] http://labourlist.org/2014/09/an-appeal-to-women-in-scotland-sisters-we-are-better-

together/

Hiilamo, H. and O. Kangas (2009) 'Trap for Women or Freedom to Choose? The Struggle over Cash for Child Care Schemes in Finland and Sweden' Journal of Social Policy 38(3) pp. 457-475

Irving, H. (2008) Gender and the Constitution: Equity and Agency in Comparative Constitutional Design (New York: Cambridge University Press)

Keating, M., P. Cairney and E. Hepburn (2009) 'Territorial Policy Communities and Devolution in the United Kingdom', Cambridge Journal of Regions, Economy and Society, 2(1).

Kenny, M. (2014) 'Engendering the independence debate' Scottish Affairs, 23(3) pp. 323-331

Kriesi, H (1996) 'The organizational structure of new social movements in a political context' in McAdam, D., McCarthy, J.D. and Zald, M.N (eds) Comparative perspectives on social movements: Political opportunities, mobilizing structures, and cultural framings (Cambridge: Cambridge University Press) pp 152-184

Kriesi, H., R. Koopmans, J.W. Duyvendak and M.G. Giugni (1995) New Social Movements in Western Europe (Minneapolis: University of Minnesota Press)

Leduc, L. (2002) 'Opinion change and voting behaviour in referendums', European Journal of Political Research, 41(6), pp. 711-732

Mackay, F. (2008) 'The state of women's movements in Britain: Ambiguity, complexity and challenges from the periphery' in Grey, S. and Sawer, M. (eds) Women's movements: Flourishing or in abeyance? (London: Routledge) pp. 17-32 
McAdam, D., McCathy, J.D., and Zald, M.N. (1996) 'Introduction: Opportunities, mobilizing structures and framing processes - toward a synthetic, comparative perspective on social movements' in McAdam, D., McCarthy, J.D. and Zald, M.N (eds) Comparative perspectives on social movements: Political opportunities, mobilizing structures, and cultural framings (Cambridge: Cambridge University Press) pp. 1-20

McAngus, C. and Rummery, K. (2014) 'A More Gender-Equal Scotland? Childcare Policy in Scotland after the Independence Referendum' in 'Keating, M. (ed) $A$ Wealthier, Fairer Scotland: The Political Economy of Constitutional Change, (Edinburgh: Edinburgh University Press) pp. 94-109

McCammon, H.J., K.E. Campbell, E. M. Granberg and C. Mowery (2001) 'How Movements Win: Gendered Opportunity Structures and U.S. Women's Suffrage Movements, 1866 to 1919', American Sociological Review, 66(1) pp. 49-70

McCarthy, J.D. (1996) 'Constraints and opportunities in adopting, adapting and inventing' in McAdam, D., McCarthy, J.D. and Zald, M.N (eds) Comparative perspectives on social movements: Political opportunities, mobilizing structures, and cultural framings (Cambridge: Cambridge University Press) pp. 141-151

Mitchell, J. (2009) Devolution in the UK (Manchester: Manchester University Press)

Mitchell, J. (2014a) The Scottish Question (Oxford: Oxford University Press)

Mitchell, J. (2014b) 'State of the Debate: Evaluating the campaigns', Centre on Constitutional Change Blog, 10 th September 2014[accessed $31^{\text {st }}$ March 2016] http://www.centreonconstitutionalchange.ac.uk/blog/state-debate-evaluatingcampaigns

O'Leary, C. and T. Hesketh (1988) 'The Irish abortion and divorce referendum campaigns', IrishPolitical Studies, 3(1), pp. 43-62

Quinlan, S., Shephard, M. and Paterson, L. (2015) 'Online discussion and the 2014 Scottish independence referendum: flaming keyboards or forums for deliberation?' Electoral Studies, 38(1), pp. 192-205

Sawer, M and Grey, S. (2008) 'Introduction' in Grey, S. and Sawer, M. (eds) Women's movements: Flourishing or in abeyance? (London: Routledge) pp. 1-16

Sawer M. and Jamieson, G (2014) 'The Women's Movement and Government', Australian Feminist Studies, 29(82), pp. 403-418,

Schuck, A.R.T. and de Vreese, C.H. (2009) 'Reversed Mobilization in Referendum Campaigns How Positive News Framing Can Mobilize the Skeptics', International Journal of Press/Politics, 14(1), pp. 40-6

Scotsman, The (2014) Scottish independence: No camp launches women book, 28th August [accessed 24th March 2015] http://www.scotsman.com/news/politics/topstories/scottish-independence-no-camp-launches-women-book-13523376? fid $=16294 \&$ isc $=1$ \&did=custom $.5184 \&$ ctp $=$ article

Women Together (2014a) Women Together Twitter Homepage [accessed 24th March 2015] https://twitter.com/WomenTogetherUK 
Women Together (2014b) Women Together Tweet, 17th September 2014 [accessed 24th March 2015]

https://twitter.com/WomenTogetherUK/status/512345368411918336

Women Together (2014c) Women Together Tweet, 16th September 2014 [accessed 24th March 2015]

https://twitter.com/WomenTogetherUK/status/511982924669808640

\footnotetext{
' Much of the SPA's material can be accessed via Flickr (https://www.flickr.com/) by typing the catalogue number in the search bar but replacing the 'forward slash' with a 'full stop' (for example SPA/2558 becomes SPA.2558). Not all of the material is available through Flickr. The available material tends to be leaflets, flyers and posters, with lengthier materials available in the archive at the University of Stirling only.

ii Indeed, one such advertised meeting advertised did not feature an address, but rather stated that the event would take place 'in the West End of Glasgow'.

iii A volunteer at the Scottish Political Archive discussed her experiences at three WT events. At two events in Glasgow and Perth there was a very poor turnout, and the Glasgow event was cancelled because the organised panel did not turn up. At a third event in Stirling there was a better turnout. At the Stirling event, the format was more lecture than engagement orientated. Furthermore, the volunteer stated that WT prohibited her from taking photographs or collecting materials to take back to the archive. This was, according to the volunteer, in stark contrast to WFI who were happy for her to take photographs and were keen for her to take away their materials.
} 